\title{
THE IMPACT OF LEADERSHIP BEHAVIOR ON SCHOOL PERFORMANCE
}

\author{
Nandang Hidayat*, Farida Wulandari \\ Universitas Pakuan, Indonesia \\ *e-mail: mr.nandanghidayat@unpak.ac.id
}

\begin{abstract}
Principal leadership is an important component that determines the direction and achievement of school performance. The purpose of this study was to identify the behavior and formulate a theoretical model of the Structural Equation Model (SEM) dimension of the principal leadership on school performance. This study used a qualitative approach using the phenomenological method. Participants in this study were 8 principals and 16 teachers from 8 private junior high schools in the Bogor City and Regency. Data collection employed in-depth interview techniques, observation of work behavior, and document review. Data validity was based on credibility, transferability, dependability and confirmability criteria during the data collection. Data analysis was carried out through the stages of organizing data, sorting them into manageable units, searching and finding patterns, synthesizing, and drawing conclusions. This research finds the following: 1) the leadership behavior of private secondary school principals to achieve optimal school performance tends to be situational and conditional; 2) interrelation in the form of direct or indirect causal relationships between the principal leadership behavior and the school performance can be formulated in the form of the theoretical SEM consisting of a four-level dimension of the principal leadership.
\end{abstract}

\section{Keywords: leadership behavior, school performance, Structural Equation Model}

\section{DAMPAK PERILAKU KEPEMIMPINAN TERHADAP KINERJA SEKOLAH}

\begin{abstract}
Abstrak: Kepemimpinan kepala sekolah merupakan komponen penting yang menentukan jalannya organisasi sekolah dan pencapaian kinerja sekolah. Tujuan penelitian ini adalah untuk mengidentifikasi perilaku dan merumuskan model teoretis dimensi Structural Equation Model (SEM) kepemimpinan kepala sekolah pada kinerja sekolah. Penelitian ini menggunakan pendekatan kualitatif dan metode fenomenologis. Penelitian ini melibatkan partisipan sebanyak 8 Kepala Sekolah dan 16 Guru dari 8 Sekolah Menengah Pertama Swasta di Kota dan Kabupaten Bogor. Pengumpulan data menggunakan teknik wawancara mendalam, observasi perilaku kerja, dan telaah dokumen. Keabsahan data didasarkan pada kriteria kredibilitas, transferabilitas, dependabilitas, dan konfirmabilitas selama proses pengumpulan data. Analisis data dilakukan melalui tahapan mengorganisasikan data, memilahnya menjadi satuan yang dapat dikelola, mencari dan menemukan pola, mensintesis, dan menarik simpulan sesuai fokus masalah yang diteliti. Penelitian ini menghasilkan simpulan: 1) perilaku kepemimpinan kepala sekolah menengah pertama swasta untuk mencapai kinerja sekolah yang optimal cenderung bersifat situasional dan kondisional; 2) interelasi dalam bentuk hubungan kausalitas langsung atau tidak langsung antara faktor-faktor perilaku kepemimpinan kepala sekolah terhadap kinerja sekolah dapat dirumuskan dalam bentuk SEM teoretik yang tersusun dalam empat level dimensi kepemimpinan kepala sekolah.
\end{abstract}

Kata Kunci: perilaku kepemimpinan, kinerja sekolah, Structural Equation Model

\section{INTRODUCTION}

The main function of a principal's leadership is to influence and to facilitate the effort of the educators and educational staff both individually and collectively so synergistically are able to conduct their tasks to achieve school goals. As a leader, the principal is able to improve school performance by influencing in a process that determining the achievement of school performance. In carrying out its functions, school needs a leader as a captain in managing and utilizing all potential of the school. Principal acts as a manager, the principal takes a role as a manager in managing the school, so he is 
demanded to have qualified leadership abilities. The main character that must be possessed by a successful leader to achieve performance is an encouragement that includes achievement motivation, ambition, energy, tenacity, initiative, leadership motivation, honesty and integrity, confidence, cognitive ability, and business knowledge (Malo, 2011).

The principal leadership is the spirit that becomes the driving force of the school organization to achieve its goals. The principal's leadership behavior must be able to encourage optimal performance of educators or teachers and other education personnel through a variety of mentoring processes, briefing, coaching, supervision, evaluation, and reflection on the teachers and educational staff, both individually and as a group. Al principals' leadership activities must be directed towards improving the quality of the school services to students as their main targets. In this case, the application of instructional leadership strategies is one of the keys to the success of school principals in encouraging improvement in the performance of educators, education personnel, student achievements (Surachmi, 2015; Usman, 2015), and student character (Suriansyah \& Aslamiah, 2015).

Organizational performance is one of the most important constructs in management research (Richard, Devinney, Yip, \& Johnson, 2009). Organization performance measurement is a management tool used to improve the quality of decision making and accountability (Gregory \& Whittaker, 2007), encourage the achievement of organization goals and provide feedback for continuous improvement efforts (Bastian \& Muchlish, 2012). Performance is multidimensional so it must be measured based on comparison with various criteria or standards (Rauch, Wiklund, Lumpkin, \& Frese, 2009).

Organization performancecan bemeasured through effectiveness, efficiency, relevance, and financial sustainability dimensions (Lusthaus, Adrien, Anderson, Carden, \& Montalvan, 2002; Lusthaus, Anderson, \& Murphy, 2004). Jing (2017) has conducted performance measurement by using six performance parameters, they are financial results, staff and customers satisfaction, productivity, retaining staff, and manager retention. Diversity as a result of different alternative resource allocation, different organizational designs alternative, and different distribution and assignment for each organization chooses (Barclay \& Osei-Bryson, 2010). From the description above it appears that there are so many dimensions that can be used as reference for measuring organization performance.

Performance achievement of an organization certainly depends on how the performance is managed. Performance management is a philosophy about managing human behavior that aims to facilitate and support the conformity of goal between individual and organization goals in order to produce organizational and financial performance (Whitford \& Coetsee, 2012). Performance management is a system where an organization sets goals, determines performance standard, appoints employees to do something and evaluates it at the same time, gives feedback, determine training and development needs and provide rewards to employees (Claus \& Briscoe, 2009; Gotcheva, 2009). Performance management is a process that contributes to the effectiveness of individual and team management in order to achieve very high level of organizational performance (Terracciano, 2017).

In relation with school organization, school performance can be measured from the effectiveness, quality, productivity, efficiency, innovation, quality of life, and work morale (Septiyani, Soegito, \& Nurkolis, 2017), input, process and outcomes (Hopkins, Day, Hadfield, Hargreaves, \& Chapman, 2003; Hoy \& Miskel, 2006). A school is an education unit that functions as a place for development of student through various activities in the process of educational services. Students are the main target or center of attention that get the service while the principal, teachers, and other education personnel are professionals who are required to carry out their duties and continuously innovating for the progress of the school to provide the best service to students.

The important goal in many studies about leadership is to identify the behavior aspect that explaining the leader's influence to a team performance, work unit or organization. The leadership behaviors used in this research was refer to Yukl's leadership theory that was grouping the leadership behavior into three meta-category hierarchies, namely task-oriented 
behavior, relationship-oriented behavior, and change-oriented behavior (Yukl, Gary, Gordon, $\&$ Taber, 2007). Based on the results of further studies, Yukl (2012) added a new leadership orientation category to become four categories. The four categories and the taxonomic hierarchy of their leadership behaviors are presented in Table 1.

The final result of good principal leadership is achieving optimal school performance. However, the facts of the preliminary survey results indicate a gap between expectations and reality. In this case, based on the results of interviews with the principal obtained a picture that the headmaster had tried to carry out leadership well, but the achievement of the school's performance was not optimal as expected. For example, the number of certified educators is still small, there are still students absent without a clear reason, the accreditation status achieved has not met expectations, and there is still a lack of achievement or appreciation received by students, schools, principals, and teachers both at the city/district level especially the national level.

One of the keys to the success of schools in an effort to improve their performance is the leadership behavior of the principal. In this case, what actions must be taken by the principal in dealing with various situations in order to have an impact on optimizing the use of all the resources owned so that it leads to improving school performance. From this point of view, one of the ways to improve school performance is by correcting the weaknesses or mistakes of the principal in carrying out his leadership function. This study tries to examine the leadership behavior of the principal and identify weaknesses that should be of concern to the principal.

The purpose of this study is to explore the tendency of principals' leadership behavior in dealing with a variety of situations during their leadership so that the performance of their schools is optimal. In addition, this study also aims to identify the dimensions and factors of leadership and formulate a theoretical model of Structural Equation Model (SEM) of the leadership behavior of principals on school performance. The resulting theoretical SEM can provide an overview of various factors at each level of the principal's leadership dimensions in utilizing all school resources towards achieving school performance. This theoretical SEM can provide a comprehensive understanding of the causal relationship either directly or indirectly between the factors of principals' leadership behavior at each level of leadership dimensions and their impact on school performance. The results of this study are expected to be used as input and consideration for school principals and stakeholders in their efforts to improve school performance.

Table 1. Yukl's Leadership Behavior Taxonomy

\begin{tabular}{ll}
\hline Leader Orientation & Hierarchy Leader Behavior Taxonomy \\
\hline Task-oriented & Clarifying \\
& Planning \\
& Operation monitoring \\
& Problem solving \\
Relationship-oriented & Supporting \\
& Developing \\
& Identifying \\
Ehange-oriented & Empowering \\
& Advocating for change \\
& Imagine change \\
& Encouraging innovation \\
Eksternal & Facilitate collective learning \\
& Networking \\
& External monitoring \\
& Representing \\
\hline
\end{tabular}

Source: Yukl (2012) 


\section{METHODS}

\section{Research Design}

This study uses a qualitative approach and the method or type of research used is the phenomenological method (Sammons, Gu, Day, \& Ko, 2011). This study explores data to find meaning from the basic and essential things of phenomena, reality, or events experienced by the principal as an object of research in carrying out his leadership function. The main informants in this study were the principal and the accompanying informant for triangulation was the teacher.

This study seeks to explore and interpret the principals' leadership behaviors as the focus of the phenomenon under study and examine various subjective aspects of the principal's actions in relation to the achievement of school performance. In-depth excavations were carried out to identify the factors that underlie the principal in carrying out each of his actions. The factors identified are then grouped according to the level of leadership dimension. Then the pathway is analyzed to explore the direct or indirect effect on school performance. Based on the path analysis, a hypothetical Structural Equation Model (SEM) of school leadership behavior towards school performance was formulated in the form of multilevel models (Sebastian \& Allensworth, 2012).

\section{Participant}

This study involved 8 principals and 16 teachers from 8 private junior high schools in Bogor city and Bogor district. The determination of private junior high schools as the research locus was carried out purposively by taking into account school performance indicators in terms of input, process, output, and outcomes in the last three years. Some of the indicators used as the basis include the completeness of school infrastructure, the number of certified educators, the presence of teachers and students, the status of accreditation, and the achievement of students, schools, principals and teachers. Demographic data of study participants are presented in Table 2.

Table 2. Research Participants

\begin{tabular}{|c|c|c|c|c|}
\hline No. & Demographic Aspects & & $\begin{array}{l}\text { Principals } \\
\quad(N=8)\end{array}$ & $\begin{array}{l}\text { Teachers } \\
(N=16)\end{array}$ \\
\hline \multirow[t]{2}{*}{1.} & Gender & $\mathrm{M}$ & 4 & 9 \\
\hline & & $\mathrm{F}$ & 4 & 7 \\
\hline \multirow[t]{3}{*}{2.} & Age & $<30$ years & - & 2 \\
\hline & & $30-40$ years & 1 & 12 \\
\hline & & $40-50$ years & 7 & 2 \\
\hline \multirow[t]{2}{*}{3.} & Education & S1 & 7 & 16 \\
\hline & & S2 & 1 & - \\
\hline \multirow[t]{3}{*}{4.} & Experience of being a & $<5$ years & 2 & - \\
\hline & school principal & $5-10$ years & 5 & 2 \\
\hline & & $>10$ years & 1 & - \\
\hline \multirow[t]{4}{*}{5.} & Teaching experience & $<5$ years & - & 2 \\
\hline & & $5-10$ years & 2 & 7 \\
\hline & & $10-20$ years & 4 & 5 \\
\hline & & $>20$ years & 2 & 2 \\
\hline
\end{tabular}

\section{Data Collection}

Data collection using in-depth interview technique as the main data collection technique. Checking the validity of the interview data was carried out through triangulation of data sources and different data collection techniques, namely by observing work behavior and reviewing related documents. Interviews with principals were conducted through face-to-face sessions at schools. Interviews with teachers were conducted in two ways, namely Focus Group Discussions (FGD) and one-on-one sessions. Interviews with 
school principals and teachers were conducted repeatedly until the expected data were obtained in this study. Observation of work behavior includes all activities of school principals and teachers while in school. Document review includes all documents relevant to the data to be collected in this study.
The focus of data collection was grouped into eleven situations faced by the principal in carrying out his leadership duties. The same focus was used for both the principal as the main informant and the teacher to triangulate. The eleven situations that are the focus of data collection are presented in Table 3.

Table 3. Focus of Data Collection

\begin{tabular}{|c|c|c|}
\hline No. & Situasion Faced by the Principal & Focus of Data Collection \\
\hline 1. & $\begin{array}{l}\text { Instilling teacher awareness of ethics, norm, } \\
\text { standard, procedure, criteria, policy, and regulations }\end{array}$ & $\begin{array}{l}\text { The situasion faced and the actions of } \\
\text { the principal }\end{array}$ \\
\hline 2. & $\begin{array}{l}\text { Policy implementation, procedure, guidelines, or } \\
\text { other }\end{array}$ & $\begin{array}{l}\text { Examples of events and principal's } \\
\text { actions }\end{array}$ \\
\hline 3. & $\begin{array}{l}\text { Steps in the development of human resources in } \\
\text { school }\end{array}$ & Steps taken by principal \\
\hline 4. & Instilling trust in teachers/staff as credible leaders & Steps and actions taken by principal \\
\hline 5. & Teacher and staff performance improvement & $\begin{array}{l}\text { Examples of special procedures or } \\
\text { processes that are prepared or designed }\end{array}$ \\
\hline 6. & Error in making decisions & $\begin{array}{l}\text { Action in dealing with this situation } \\
\text { and its results }\end{array}$ \\
\hline 7. & $\begin{array}{l}\text { Teacher performance is low or not in line with } \\
\text { expectations }\end{array}$ & $\begin{array}{l}\text { The causes and actions that are } \\
\text { committed by principal }\end{array}$ \\
\hline 8. & Have to make a decision in a difficult situation & $\begin{array}{l}\text { An example of situation as well as how } \\
\text { the principal behaves and acts }\end{array}$ \\
\hline 9. & $\begin{array}{l}\text { Teacher and staff behave not according to norms, } \\
\text { ethics, and regulations }\end{array}$ & $\begin{array}{l}\text { Reaction, action, and effect on teacher/ } \\
\text { staff behavior }\end{array}$ \\
\hline 10. & $\begin{array}{l}\text { Conflict of interest with teacher, staff, students, } \\
\text { school committees, or other parties (stakeholders) }\end{array}$ & Action and reason for those actions \\
\hline 11. & Work as part of a team & $\begin{array}{l}\text { Role and action taken so that the team } \\
\text { able to work optimally }\end{array}$ \\
\hline
\end{tabular}

\section{Data Analysis}

Data analysis was carried out through the stages of reducing and organizing data from interviews, observation, and document review, grouping into manageable units, presenting grouped data, searching and finding patterns, synthesizing, and drawing conclusions. To ensure the quality of the results of data analysis in this study, the analysis of interview data for each research focus was cross-checked with observation data and related document reviews. To ensure the validity of the data generated, the triangulation and iteration process was carried out while maintaining credibility, transferability, dependability and confirmability during data collection (Williamson, Given, \& Scifleet, 2018).

\section{FINDINGS AND DISCUSSION Findings Principal's Leadership Behavior}

Theresults of data analysis from interviews, field observations, and documentation studies on the leadership behavior of school principals in various situations that are the focus of the study in this study found a number of unique and distinctive patterns of behavior. The behavioral synthesis constituting the findings of this study is presented in Table 4. Based on the behavior of school principals as presented in Table 4, it appears that the principal has tried to take the best actions in order to encourage an increase in the performance of educators and education personnel so that it has an impact on school performance. However, through this research, it was found that there were three weaknesses in 
the behavior of school principals in carrying out their roles as leaders, namely: 1) development of collaborative networks with various parties, 2) concrete efforts to improve teacher performance in terms of professionalism as educators; 3 ) increasing active teacher participation, such as actively participating in seminars and workshops related to the main duties and functions of teachers.

Table 4. Principal's Leadership Behavior in Various Situations

\begin{tabular}{cl}
\hline No. & Focus of Data Collection \\
\hline 1. & $\begin{array}{l}\text { Instilling teacherawareness } \\
\text { of ethics, norm, standard, } \\
\text { procedure, criteria, policy, } \\
\text { and regulations }\end{array}$ \\
2. & $\begin{array}{l}\text { Policy implementation, } \\
\text { procedure, guidelines, or } \\
\text { other }\end{array}$ \\
3. & $\begin{array}{l}\text { Steps in the development } \\
\text { of human resources in } \\
\text { school }\end{array}$
\end{tabular}

4. Instilling trust in teachers/ staff as credible leaders

5. Teacher and staff performance improvement

6. Error in making decisions

7. Teacher performance is low or not in line with expectations

8. Have to make a decision in a difficult situation

9. Teacher and staff behave not according to norms, ethics, and regulations

10 Conflict of interest with teacher, staff, students, school committees, or other parties (stakeholders)

11. Work as part of a team

\section{Principal's Leadership Behavior}

Clarifying in writing through standard operating procedures or verbally delivered in a meeting at the end of the semester or in a routine meeting.

Preparation of program plans, activities, guidelines, etc. Involves educators, educational staff, and school committee representatives. Supervising, guiding, and coaching in its implementation and evaluating the results regularly.

Facilitating and requiring all teachers to be active in MGMP activities, attend seminars, training, workshops, or other scientific activities, provide scholarships for further education, hold training or workshops at the end of each year at schools by inviting outside experts, and facilitating teachers who are not yet certified to attend Pendidikan Profesi Guru (PPG).

Implementing lifelong learning, always innovating, advocating to educators and education personnel, responsive to criticism and suggestions, and trying to recognize the characteristics of each educator and educational staff, so that they understand the actions needed to serve and meet their needs.

Clarify every task that must be completed, jointly design programs and targets, conduct continuous supervision, coaching and directing, and resolve problems that arise immediately.

Each decision is discussed first by involving educators and education personnel and before it is decided, it is consulted with the organizing foundation.

Evaluating performance objectively and transparently, conducting one-one sessions, applying the principles of reward and punishment, fulfilling rights according to regulations, and opening career opportunities according to achievement.

Consult each case with applicable regulations both from the government and from schools / foundations, so that decisions taken do not conflict with these rules.

In general, principals use a problem-solving approach rather than imposing sanctions.

Taking personal approaches with conflicting parties and delaying conflict resolution time to calm their emotions. Conflict resolution is done by focusing on the problems that cause conflict and trying not to touch personal problems. If the conflict cannot be resolved internally at the school, then ask for help from the organizing foundation.

Disseminate the vision and mission of the school to all school members in various ways, build a positive work culture, develop information system management, and carry out activities that can build a sense of togetherness on a regular basis. 


\section{Structural Equation Model Principal's Leadership on School Performance}

Actions taken in dealing with various situations and utilizing all resources owned by the school are basically the efforts of the principal to achieve optimal school performance. The consistency of the actions of the principal shows the pattern of leadership behavior exhibited by the principal. Every principal's action is certainly triggered by a number of factors or variables. These factors are interrelated causally and contribute either directly or indirectly to the achievement of school performance.

In-depth interviews with principals, teachers, and related document review are conducted to explore and identify factors or variables within the scope of the principal's leadership dimensions which are predicted to contribute to school performance. Rational analysis with reference to the theory and results of research that examines the relationship between leadership variables with school performance is carried out to formulate the Structural Equation Model (SEM) of school leadership variables on school performance. For the purposes of SEM formulation, the factors that have been identified are further grouped into four levels of leadership dimensions as shown in Table 5.

Table 5. Distribution of Factors/Variables for Each Level of Leadership Dimension

\begin{tabular}{lll}
\hline $\begin{array}{l}\text { Leadership } \\
\text { Dimension }\end{array}$ & Factors/Variables \\
\hline Level 1 & 1. & School planning \\
& 2. & School organization design \\
& 3. & Trust of the school organizing \\
& & foundation \\
& 4. & Principal trust \\
& 5. & Observation and supervision \\
& 6. & Human resources depelopment \\
Level 2 & 7. & Data utilization \\
& 1. & Division of task \\
& 2. & Administrative staff leadership \\
& 3. & Teacher colaboration trough MGMP \\
& 4. & Learning quality \\
Level 3 & 5. & Teacher performance \\
& 1. & Improving school condition \\
& 2. & Assessment for feedback \\
& 3. & Internal dan external colaboration \\
& 4. & culture \\
Level 4 & 1. & Increased student learning outcomes \\
& 2. Increased student attendance \\
& 3. Motivation, enthusiasm, behaviour, \\
& 4. dan learning culture
\end{tabular}

At the level 1 leadership dimension, two main factors or variables of headmaster leadership were identified, namely "school plans" and "school organization design". From these two main variables, three other variables can be identified that are suspected to be directly related, namely "human resource development", "observation and supervision", and "data utilization". The causality relationship between the five variables forms a separate system. The first two variables, namely "school plans" and "school organization design" interact with each other and both directly affect three other variables, namely "human resource development", "observation and supervision", and "data utilization". Two other variables outside the five variables work as exogenous variables, namely "the trust of the principal" and "the trust of the organizing foundation". The variable "trust foundation organizers" operate through "principals' trust" which functions as an endogenous variable to the first two variables, namely "school organization design" and "school planning". Thus, at the level 1 leadership dimension, there are seven factors or variables that form a structural model in the principal's leadership practices.

At the level 2 leadership dimension there are five factors or variables, namely "division of tasks", "administration staff leadership", "teacher collaboration through Musyawarah Guru Mata Pelajaran (MGMP)", "learning quality", and "teacher performance". This study shows that the "school trust" factor in the level 1 leadership dimension is thought to have a direct effect on five factors in the level 2 leadership dimension. The "school planning" and "school organization design" factors have an indirect effect on "task division" and "leadership administrative staff "which is operated through the" human resource development "factor as an intermediate or endogenous variable. The factor of "division of leadership tasks" and "teacher collaboration through MGMP" is thought to contribute and influence directly on "leadership of administrative staff". These factors are supported by the statement of school principals and teachers that "the division of leadership tasks" and "teacher collaboration through MGMP" will work well if they receive adequate support from the "leadership staff administrative factors". Meanwhile it is suspected that "teacher 
collaboration through MGMP" contributes indirectly to "teacher performance" which operates through "learning quality" as an intermediate or endogenous variable. This fact shows that "teacher collaboration through MGMP" will have an impact on "teacher performance" if that factor can improve "learning quality".

At the level 3 leadership dimension there are five factors or variables, namely "culture of internal and external collaboration", "utilization of learning opportunity", "assessment for feedback", and "improving school conditions". It was suspected that "school organization design" factor of leadership dimension of level 1 has contributed on direct influence to "school condition improvement". It was suspected that "principal trust" factor did not influence directly to all factors or variables of level 3 leadership dimension, but it worked through the level 2 leadership dimension factors as an intermediate variable or endogenous. Meanwhile, leadership dimension factors of level 3 indicated relationship of one and another dimension. In this case, "internal and external collaboration culture" was suspected to have direct relation with "utilization of learning opportunity" and "assessment for feedback", so it became an endogenous variable of "division of task", "administrative staff leadership", and "teacher collaboration through MGMP" factors. However, there was no data that lead to the alleged relationship between "improving school condition" factor with three other factors of the level 3 leadership dimension.

Level 4 consists of four factors, they are "motivation, enthusiasm, behavior, and learning culture", "increased of learning outcomes", "increasing in student attendance", "school performance" factors. It was suspected that these four factors were interconnected both directly and indirectly, thus it formed its own structural model. Factor of "motivation, enthusiasm, behavior, and learning culture", and "increasing in student attendance" revealed that there was direct or indirect relationship of the two factors with "school performance" where "the increasing in learning outcomes" became an intermediate variable or endogenous. It was suspected that factors of the level 3 leadership dimension had not direct relation with "school performance", but all factors worked through the first three in the level 4 leadership dimension, which were "motivation, enthusiasm, behavior, and learning culture", "increased of learning outcomes", and "increasing in student attendance". Meanwhile, it was also found out that there were data which lead to allegation that the factors of "division of leadership task" and "teacher performance" had a direct influence on "the school performance". "School performance" factor was the dependent variable that became the final estuary of the alleged SEM in this study.

The alleged SEM that resulting from explorative research which was the initial research of the mixed-method research was presented in Figure 1.

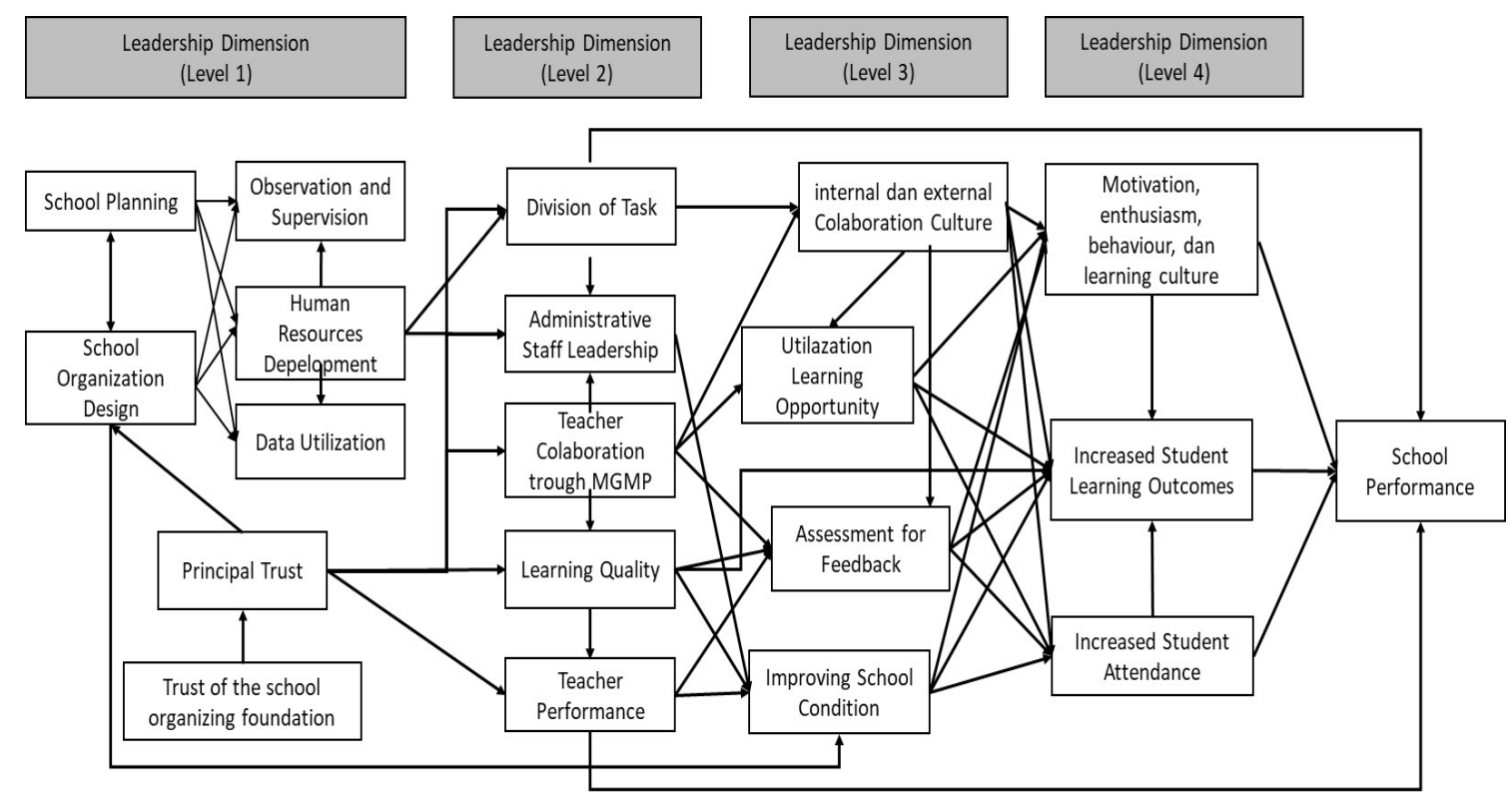

Figure 1. Alleged SEM of Leadership Dimension with School Performance 


\section{Discussion}

\section{Principal's Leadership Behavior}

One of the findings in this research was that leadership developed by the principal was more situational depending on the case or problem faced by the principal in carrying out his leadership. It means, from the four tendencies of leadership orientation according to Yukl (2012), there was no tendency of typical leadership orientation adopted by the principal. This finding showed that during carrying out his leadership's function, the principal did not fixate on one tendency leadership orientation (task-oriented, relationship, change, or external). Actions or leadership behavior which were exhibited by the principal were stressed more on the situation or problem facing, so the action taken was more stressed on the needs of problem solving and effort to encourage the optimal school performance.

The findings were in line with result of the research by Bruner, Grennlee, \& SomersHill (2007) that stated school change requires a metacognitive and reflective troubleshooter leader. It means, the principal that acted as a manager was required to be able to take an appropriate action depend on the problem and the condition facing that made him able to encourage the school organization performance in the near future. In the relation with the principal's leadership, all of the principal leadership activities must be directed to encourage the improvement of the school services to students as the main target (Malo, 2011), principal must supervise and monitor the progress of teachers in class (Ediger, 2014).

These findings illustrated that the principal leadership through their actions in various situations became variables that influenced the effectiveness and efficiency of the teacher and staff during carrying out their duty. These findings were supported by another research that showed a principal's leadership was a variable that can be raised up teacher's efficiency although it could also reduce this capacity whenever the school leadership was not effective (Soehner \& Ryan, 2012). As a leader, the principal guided the school to teach and study better (Wallace Foundation, 2013). Another research result were also showed a greater effect of principal leadership if compared to the teacher leadership's sources in relation to student involvement.
The principal leadership effect was weak but significant, but the teacher leadership effect was not significant. Both forms of leaderships were mediated by many of the same elements of the school organization (Leithwood \& Jantzi, 1999).

This study also found that school principals had relatively high self-efficacy in deciding what actions to take in various situations faced. Although in making their decisions, they always consult with the organizer of the foundation, but the final decision is in their hands. In order to support the principal's effectiveness in carrying out his leadership function, a principal must pose high self-efficacy. Related to this matter, a study found out that principal self-efficacy confidence was important because it guided action and leader's behavior that affected student expectation and teachers' motivation and also school improvement process (Versland \& Erickson, 2017). It means the findings of this research were also support the need for a study about principal self-efficacy and various operational efforts to improve it.

The results of this study also found that the actions of school principals who were relatively well turned out to be not directly in line with school performance achievements. However, a number of studies have shown that the principal's leadership contributes to teacher performance (Apriani, Maria, \& Yulianto, 2017; Octavia \& Savira, 2016), teacher work productivity (Lestari, Hidayat, \& Putra, 2018) and students' outcomes (Pina, Cabral, \& Alves, 2015). This finding gives a clue that school performance is not only determined by the principal's leadership variable, but there are a number of other variables. Therefore, an in-depth study needs to be carried out to identify other variables that contribute to school performance.

The study also found that school principals did not exhibit behaviors that lead to change-oriented leadership. There are no principal actions that can be categorized into change-oriented leadership. In fact, changeoriented leadership behavior which in practice is realized in the form of transformational leadership is very important to encourage improvement in school performance so that it becomes an effective school (Allen, Grigsby, \& Peters, 2015; Yang, 2014). Meanwhile, change is a characteristic of life in the industrial era 4.0 and the digital era which is currently happening 
(Fitriyah \& Santosa, 2020; Wening \& Santosa, 2020). Therefore, it is necessary to design training programs that can guide principals to better understand and be able to implement change-oriented or transformational leadership in their schools.

\section{Structural Equation Model Principal's Leadership on School Performance}

This research was also found out that there were several dimension factors of principal's leadership and its interrelation with school performance. Based on the results of a rational study of these factors, they were then positioned as estrogen and endogen variable to increase school performance and then were grouped into four levels or stages of leadership dimension of SEM principal leadership on school performance. Level 1 leadership dimension consists of six factors, namely: 1) school planning, 2) school organization design, 3) principal trust, 4) observation and supervision, 5) human resources development, and 6) data utilization. Level 2 leadership dimension with five factors, namely: 1) division of leadership tasks, 2) administrative leadership staff, 3) teachers collaboration through MGMP, 4) learning quality, and 5) teacher performance. Level 3 leadership dimension with four factors, namely: 1) internal and external collaboration culture, 2) utilization of learning opportunities, 3) assessment for feedback, and 4) school condition improvement. Level 4 leadership dimension with four factors, namely: 1) motivation, enthusiasm, behavior, and learning culture, 2) improvement of student learning outcomes, 3) increased student attendance, and 4) school performance.

It was suspected that factors or variables of all four leadership levels were direct or indirectly had mutual influenced on each other to form SEM of principal leadership behavior practice toward school performance improvement that could be seen in figure 4.4. Although there were differences in several factors due to difference characteristic of schools under study, these findings supported the results of research on the impact of leadership on students' outcomes (Sammons et al., 2011). However, our research was different, because the focus of the research was related to the tendency of the principal's leadership orientation. Moreover, the school performance parameters measured were not only based on increasing students' academic achievement, but based on the students' academic and non-academic achievement, national examination results, educator achievements, satisfaction of school residents, and public trust in schools.

Based on inter-relationship amongst the factors of school leadership which been formulated in conjectural SEM of principal's leadership behavior practice showed that this practiced was not directly influenced to the school performance improvement. Principal's leadership practices through several actions or his leadership behavior were indeed intended to influence the positive change of the school performance, but the changed was happened through the operation effect of teacher's performance, learning process quality, also development of a conductive climate and culture of school collaboration and emphasizing high expectation on academic and non-academic achievements of students, national examination results, educator achievements, satisfaction of school residents, and public trust in schools which were the main parameters of the school performance. The changed was supported by the research result which explained that transformational instructional leadership which took place in an integrated manner had an effect on school performance as measured by the quality of pedagogy and student achievement which was substantial (Marks \& Printy, 2003).

Although the conjectural SEM produced in this research has not been empirically tested, but reminding the importance of the practice model of principal leadership which was always: 1) building a school climate in the form of disciplined behavior, orderly, and adhere to the norms, values, and rules, 2) encouraging learning motivation to all school residents, and 3) developing collaboration culture, learning culture, utilizing feedback on the results of assessments, and continually improving the condition of the school environment. All of these variables were suspected to predict of positive change in student behavior and attendance as a midterm result which encouraged in improving academic achievement and in turn encouraged an increase in school performance.

It was in-line with the result of other relevant study about the principal's leadership that showed that variations in classroom teaching 
were linked to principals' leadership through several channels. The strongest of which were professional development quality and program coherence (Sebastian \& Allensworth, 2012). Although there was a relatively strong suitability with another relevant result research, this SEM was still conjecture that still needed empirical testing through path analysis. Further research was still needed to test whether the conjectural SEM was tested so that its structure could be maintained or needed revising and according to the results of path analysis.

\section{CONCLUSION}

The leadership behavior of private secondary school principals in carrying out their leadership functions to achieve optimal school performance tends to be situational and conditional. However, there is no evidence of change oriented school principals' behavior.

SEM theoretical practices of principals' leadership behavior towards school performance can be formulated in four levels of leadership dimensions, namely 1) Level 1 leadership dimension with seven factors: trust of the school organizing foundation, principal trust, school planning, school organization design, observation and supervision, human resources development, and data utilization; 2) Level 2 leadership dimension with five factors: division of tasks, administrative staff leadership, teacher collaboration through MGMP, learning quality, and teacher performance; 3) Level 3 leadership dimension with four factors: internal and external collaboration culture, utilization of learning opportunities, assessment for feedback, and improving school conditions; and 4) Level 4 leadership dimension with four factors: motivation, enthusiasm, learning behavior and culture, increased student learning outcomes, increased student attendance, and school performance.

\section{ACKNOWLEDGMENTS}

Our thanks to the Director and all Director Assistances of the Sekolah Pascasarjana Universitas Pakuan for providing financial support so that this research can be carried out. Thank you to the review team who provided input to revise the results of this study. Thank you to the Editor and Staff of the Jurnal Cakrawala Pendidikan for providing the opportunity to publish articles on the results of this study.

\section{REFERENCES}

Allen, N., Grigsby, B., \& Peters, M. L. (2015). Does leadership matter? Examining the relationship among transformational leadership, school climate, and student achievement. NCPEA International Journal of Educational Leadership Preparation, 10(2), 1-28. https://www. ncpeapublications.org/index.php/volume10-number-2-fall-2015/689.

Apriani, D., Maria, M. D., \& Yulianto, A. R. (2017). Korelasi kepemimpinan dan perilaku etis kepala sekolah dengan motivasi kerja dan kinerja guru SMP Pius Tegal. [Correlation of leadhership and head master's ethical behavior towards teacher's working motivation and performance]. Cakrawala: Jurnal Pendidikan, 11(2), 115-124. https://doi. org/10.24905/cakrawala.v11i2.844.

Barclay, C., \& Osei-Bryson, K. M. (2010). Project performance development framework: An approach for developing performance criteria \& measures for information systems (IS) projects. International Journal of Production Economics, 124(1), 272-292. https://doi. org/10.1016/j.ijpe.2009.11.025.

Bastian, E., \& Muchlish, M. (2012). Perceived environment uncertainty, business strategy, performance measurement systems and organizational performance. Procedia - Social and Behavioral Sciences, 65(1), 787-792. https://doi. org/10.1016/j.sbspro.2012.11.200.

Bruner, D. Y., Grennlee, B. J., \& Somers-Hill, M. (2007). The reality of leadership preparation in a rapidly changing context: Best practice vs. reality. Journal of Research on Leadership Education, 2(1), 158-198. https://doi. org/10.1177/194277510700200201.

Claus, L., \& Briscoe, D. (2009). Employee performance management across borders: A review of relevant academic literature. International Journal of Management 
Reviews, 11(2), 175-196. https://doi. org/10.1111/j.1468-2370.2008.00237.x.

Ediger, M. (2014). The changing role of the school principal. College Student Journal, 48(2), 265-267. http://ezproxy.wingate. edu/login?url=http://search.ebscohost. com $/ \operatorname{login}$. aspx?direct $=$ true $\& \mathrm{db}=\mathrm{a} 9 \mathrm{~h} \& \mathrm{~A}$ $\mathrm{N}=97002779 \&$ site $=$ ehost-live.

Fitriyah, I., \& Santosa, A. B. (2020). Kepemimpinan kepala sekolah dalam menghadapi era revolusi industri 4.0 untuk meningkatkan mutu sekolah. [Principal leadership in the era of the Industrial Revolution 4.0 is to improve the quality of school]. Jurnal Manajemen, Kepemimpinan, dan Supervisi Pendidikan, 5(1), 65-70. https://doi.org/10.31851/ jmksp.v5i1.3538.

Gotcheva, N. (2009). Book review: Dennis Briscoe, Randall Schuler and Lisbeth Claus international human resource management: Policies and practices for multinational enterprises $\left(3^{\text {rd }}\right.$ ed). London: Routledge. https://doi. org/10.1177/0950017009337067.

Gregory, A., \& Whittaker, J. (2007). Performance and performance persistence of "ethical" unit trusts in the UK. Journal of Business Finance and Accounting, 34(7-8), 13271344. https://doi.org/10.1111/j.14685957.2007.02006.x.

Harris, A., Hopkins, D., Day, C., Hadfield, M., Hargreaves, A. and Chapman, C. (2003). Effective leadership for school improvement. London, UK: Routledge.

Hoy, W. K. \& Miskel, C. G. (2006). Contemporary issues in educational policy and school outcomes. Greenwich, CT: Information Age.

Jing, F. F. (2017). Leadership paradigms and performance in small service firms. Journal of Management and Organization, 24(03), 339-358. https://doi.org/10.1017/ jmo.2017.44.

Leithwood, K., \& Jantzi, D. (1999). The relative effects of principal and teacher sources of leadership on student engagement with school. Educational Administration Quarterly, 35(5), 679-706. https://doi. org/10.1177/0013161X99355002.

Lestari, A., Hidayat, N., \& Putra, K. S. (2018). Hubungan antara kepemimpinan transformasional dan iklim organisasi dengan produktivitas kerja guru. [The relationship between transformational leadership and organizational climate with teacher work productivity]. Jurnal Manajemen Pendidikan, 6(2), 672-682. https://doi.org/10.33751/jmp.v6i2.794.

Lusthaus, C., Adrien, M.-H., Anderson, G., Carden, F., \& Montalvan, P. (2002). Organizational assessment: A framework for improving performance. Washington, DC: International Development Research Centre. https://www.idrc.ca/sites/default/ files/openebooks/998-4/index.html.

Lusthaus, C., Anderson, G., Murphy, E., Lusthaus, C., Anderson, G., \& Murphy, E. (2004). The basics of capacity, organizational capacity development, and evaluation. Ottawa, ON: Institutional Assessment a Framework for Strengthening Organizational Capacity for IDRC's Research Partners.

Malo, R. (2011). Leadeship's trait theories. In Annals of Eftimie Murgu University Resita, Fascicle II, Economic Studies. Massachusetts: EBSCO, pp. 215-220.

Marks, H. M., \& Printy, S. M. (2003). Principal leadership and school performance: An integration of transformational and instructional leadership. Educational Administration Quarterly, 39(3), 370-397. https://doi. org/10.1177/0013161X03253412.

Octavia, L.S \& Savira, S. I. (2016). Gaya kepemimpinan kepala sekolah dalam upaya meningkatkan kinerja guru dan tenaga kependidikan. [Principal leadership style in an effort to improve the performance of teachers and education personnel]. Jurnal Dinamika Manajemen Pendidikan, 1(1), 7-14. https://doi. org/10.26740/jdmp.v1n1.p7-14. 
Pina, R., Cabral, I., \& Alves, J. M. (2015). Principal's leadership on students' outcomes. Procedia - Social and Behavioral Sciences, 197, 949-954.https:// doi.org/10.1016/j.sbspro.2015.07.279.

Rauch, A., Wiklund, J., Lumpkin, G. T., \& Frese, M. (2009). Entrepreneurial orientation and business performance: An assessment of past research and suggestions for the future. Entrepreneurship: Theory and Practice, 33(3), 761-787. https://doi. org/10.1111/j.1540-6520.2009.00308.x.

Richard, P. J., Devinney, T. M., Yip, G. S., \& Johnson, G. (2009). Measuring organizational performance: Towards methodological best practice. Journal of Management, 35(3), 718-804. https://doi. org/10.1177/0149206308330560.

Sammons, P., Gu, Q., Day, C., \& Ko, J. (2011). Exploring the impact of school leadership on pupil outcomes: Results from a study of academically improved and effective schools in England. International Journal of Educational Management, 49(2), 82-103. https://doi. org/10.1108/09513541111100134.

Sebastian, J., \& Allensworth, E. (2012). The influence of principal leadership on classroom instruction and student learning: A study of mediated pathways to learning. Educational Administration Quarterly, 48(4), 626-663. https://doi. org/10.1177/0013161X11436273.

Septiyani, L., Soegito, S., \& Nurkolis, N. (2017). Strategi peningkatan mutu pendidikan melalui penerapan manajemen berbasis sekolah di SD Negeri 02 Bantarbolang Kabupaten Pemalang. [The strategy for improving the quality of education through the implementation of schoolbased management at SD Negeri 02 Bantarbolang, Pemalang Regency]. Jurnal Manajemen Pendidikan (JMP), 5(1), 21-29 https://doi.org/10.26877/jmp. v5i1.1922.

Soehner, D., \& Ryan, T. (2012). The interdependence of principal school leadership and student achievement.
Scholar-Practitioner Quarterly, 5(3), 274-288. http://files.eric.ed.gov/fulltext/ EJ974355.pdf.

Surachmi, S. (2015). Efektivitas dimensi internal kepala sekolah dalam kepemimpinan pembelajaran. [The effectiveness of the internal dimensions of the principal in learning leadership]. Cakrawala Pendidikan, 30(3), 433-448. https://doi. org/10.21831/cp.v3i3.4206.

Suriansyah, A., \& Aslamiah. (2015). Strategi kepemimpinan kepala sekolah, guru, orang tua, dan masyarakat dalam membentuk karakter siswa. [The leadership strategies of school principals, teachers, parents, and the communities in building the students' character]. Cakrawala Pendidikan, 34(2), 234-247. https://doi.org/10.21831/ cp.v2i2.4828.

Terracciano, N. (2017). Performance management at the organizational level. Annals of Spiru Haret University Economic Series, 17(2), 19-28. https:// doi.org/10.26458/1722.

Usman, H. (2015). Model kepemimpinan instruksional kepala sekolah. [The school principals' instructional leadership model]. Cakrawala Pendidikan, 34(3), 322-333. https://doi.org/10.21831/ cp.v3i3.7338.

Versland, T. M., \& Erickson, J. L. (2017). Leading by example: A case study of the influence of principal self-efficacy on collective efficacy. Cogent Education, 4(1), 1-17. https://doi.org/10.1080/23311 86X.2017.1286765.

Wallace Foundation. (2013). The school principal as leader: Guiding schools to better teaching and learning. perspective. Washington, DC: Author. https://www. wallacefoundation.org/knowledge-center/ Documents/The-School-Principal-asLeader-Guiding-Schools-to-BetterTeaching-and-Learning-2nd-Ed.pdf.

Wening, M. H., \& Santosa, A. B. (2020). Strategi kepemimpinan kepala sekolah dalam menghadapi era digital 4.0. 
[Principal leadership strategies in facing the digital era 4.0]. Jurnal Manajemen, Kepemimpinan, dan Supervisi Pendidikan, 5(1), 56-64. https://doi.org/10.31851/ jmksp.v5i1.3537.

Whitford, C. M., \& Coetsee, W. J. (2012). A model of the underlying philosophy and criteria for effective implementation of performance management. SA Journal of Human Resource Management, 4(1), 63-73. https://doi.org/10.4102/sajhrm. v4i1.78.

Williamson, K., Given, L. M., \& Scifleet, P. (2018). Qualitative data analysis. In K. Williamson, \& G. Johanson (Eds.), Research methods: Information, systems, and contexts. Prahran, VIC: Tilde University Press, pp. 417-439). https:// doi.org/10.1016/b978-0-08-102220-
7.00019-4.

Yang, Y. (2014). Principals' transformational leadership in school improvement. International Journal of Educational Management, 28(3), 279-288. https://doi. org/10.1108/IJEM-04-2013-0063.

Yukl, G. (2012). Effective leadership behavior: What we know and what questions need more attention. Academy of Management Perspectives, 26(4), 66-85. https://doi. org/10.5465/amp.2012.0088.

Yukl, Gary, Gordon, A., \& Taber, T. (2007). A hierarchical taxonomy of leadership behavior: Integrating a half century of behaviorresearch. Journalof Leadership \& OrganizationalStudies, 9(1), 15-32.https:// doi.org/10.1177/107179190200900102. 